\title{
Mutations for Worse or Better: Low Fidelity DNA Synthesis by SOS DNA Polymerase V is a Tightly-Regulated Double-Edged Sword
}

\author{
Malgorzata Jaszczur§, Jeffrey G. Bertram ${ }^{\S}$, Andrew Robinson ${ }^{\ddagger}$, Antoine M. van Oijen ${ }^{\ddagger}$, \\ Roger Woodgate\# ${ }^{\#}$ Michael M. Cox", and Myron F. Goodman $\$, \dagger,{ }^{*}$ \\ $\S$ Department of Biological Sciences, University of Southern California, Los Angeles, California, \\ United States of America \\ ¥School of Chemistry, University of Wollongong, Wollongong, Australia \\ \#Laboratory of Genomic Integrity, National Institute of Child Health and Human Development, \\ National Institutes of Health, Bethesda, Maryland, United States of America \\ "Department of Biochemistry, University of Wisconsin-Madison, Madison, Wisconsin, United \\ States of America \\ tDepartments of Biological Sciences and Chemistry, University of Southern California, Los \\ Angeles, California, United States of America
}

\section{Abstract}

1953, the year of Watson and Crick, bore witness to a less acclaimed, yet highly influential discovery. Jean Weigle demonstrated that upon infection of Escherichia coli, $\lambda$ phage deactivated by UV radiation, and thus unable to form progeny, could be reactivated by irradiation of the bacterial host. Evelyn Witkin and Miroslav Radman later revealed the presence of the SOS regulon. The more than 40 regulon genes are repressed by LexA protein and induced by the coproteolytic cleavage of LexA, catalyzed by RecA protein bound to single-stranded (ss)DNA, the RecA* nucleoprotein filament. Several SOS-induced proteins are engaged in repairing both cellular and extracellular damaged DNA. There's no "free lunch", however, because error-free repair is accompanied by error-prone translesion DNA synthesis (TLS), involving E. coli DNA polymerase $\mathrm{V}\left(\mathrm{UmuD}_{2}{ }_{2} \mathrm{C}\right)$ and $\mathrm{Rec} \mathrm{A}^{*}$. This review describes the biochemical mechanisms of pol $\mathrm{V}$-mediated TLS. Pol V is active only as a mutasomal complex, pol V Mut $=\mathrm{UmuD}_{2}{ }_{2} \mathrm{C}-\mathrm{RecA}$ ATP. RecA* donates a single RecA subunit to pol V. We highlight three recent insights: 1) pol V Mut has an intrinsic DNA-dependent ATPase activity that governs polymerase binding and dissociation from DNA; 2) active and inactive states of pol V Mut are determined at least in part by the distinct interactions between RecA and UmuC; 3) pol V is activated by RecA*, not at a blocked replisome, but at the inner cell membrane.

\section{Graphical Abstract}

\footnotetext{
*Corresponding Author. mgoodman@usc.edu. Telephone: (213) 740-5190.

The authors declare no competing financial interest.
} 


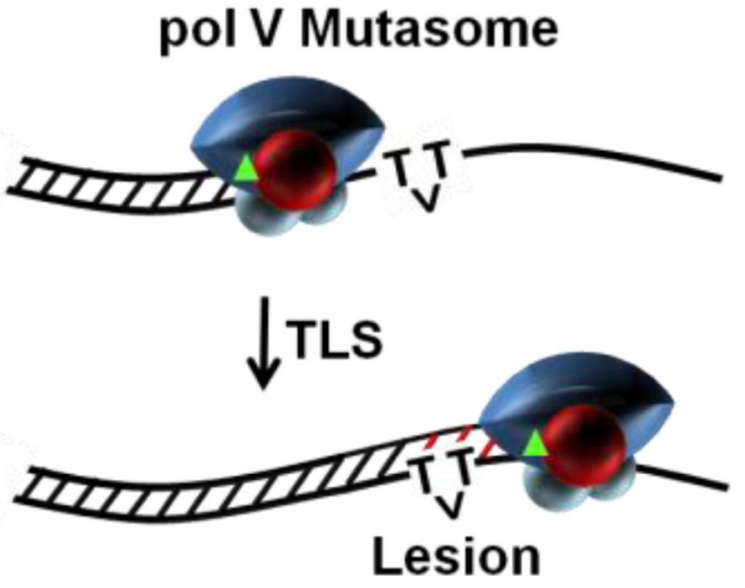

Mutations for worse are responsible for death in microorganisms and disease in humans. Mutations for better are a central driving force for fitness and evolution in all forms of life. Escherichia coli DNA polymerase V (pol V)initiates the lion's share of mutations targeted at DNA template lesions, including those caused by UV radiation and a variety of chemicals that can damage DNA. ${ }^{1-4}$ The initial description of the polymerase function of the $E$. coli DinB (pol IV) and UmuDC (pol V) proteins in $1999^{5-7}$ was part of the broader discovery of a new and widespread family of specialized DNA polymerases. ${ }^{8}$ These are the $\mathrm{Y}$ family DNA polymerases, which promote a process called translesion DNA synthesis or TLS. These polymerases exhibit a relaxed specificity, increasing mutagenesis when they function. In E. coli, pol $\mathrm{V}$ is responsible for virtually all of the mutagenesis that accompanies the SOS response. ${ }^{1-4,9,10}$

The $u m u D$ and $u m u C$ genes encoding error prone pol $\mathrm{V}\left(\mathrm{UmuD}_{2}{ }_{2} \mathrm{C}\right)$ are induced in response to DNA damage as part of the SOS regulon. ${ }^{1,2}$ The promoter for the umuDCoperon possesses a near perfect match with the consensus LexA repressor binding motif resulting in its relatively late SOS induction. The operon is not fully derepressed until 15 min after DNA damage ${ }^{11}$, and the $\mathrm{UmuD}_{2}{ }_{2} \mathrm{C}$ proteins themselves do not accumulate until $\sim 45 \mathrm{~min}$ after damage, due to rapid proteolysis of the Umu proteins. ${ }^{12}$ Once formed, pol $\mathrm{V}$ is largely resistant to proteolysis, and the enzyme copies past DNA template lesions that normally arrest replication by the high fidelity pol III. ${ }^{13}$ Low-fidelity pol V lacks intrinsic 3'-5' exonucleolytic proofreading, so it cannot correct any mistakes it makes during TLS. However, if the pol V -dependent TLS tract is limited, then any misincorporated nucleotides introduced by pol V during TLS may be subject to extrinsic proofreading by the $d n a Q-$ encoded epsilon subunit of pol III. The extent of extrinsic proofreading may be temporarily suppressed due to an increase in nucleotide pools that accompany the SOS response, ${ }^{14}$ and may allow pol III to elongate pol V-catalyzed misincorporations and thereby help sustain them as damage-induced mutations in the E. coli genome. $^{14}$

RecA bound to single-stranded (ss) DNA in the presence of ATP as an active and extended nucleoprotein filament is often referred to as RecA*. ${ }^{15}$ RecA has multiple roles in the SOS response, and its effects are paramount to both SOS regulation and downstream implementation. RecA* appears when RecA binds to the ssDNA byproduct of DNA damage 
events. Acting as a coprotease, RecA* induces the SOS response by facilitating the autocatalytic cleavage of the LexA repressor protein to upregulate transcription of the SOS regulon genes(Figure 1). ${ }^{16}$ The RecA* coprotease activity is again needed to form pol $\mathrm{V}$ by facilitating the autocatalytic cleavage of the UmuD protein to a shorter and mutagenically active $\mathrm{UmuD}^{\prime 9,17,18}$ that dimerizes and binds to $\mathrm{UmuC}^{19}$ (Figure 1). Finally, $\mathrm{UmuD}_{2}{ }_{2} \mathrm{C}$ is activated by transfer of a RecA subunit from RecA* to $\mathrm{UmuD}_{2}{ }_{2} \mathrm{C}$ to form pol V Mut (UmuD ${ }_{2} \mathrm{C}$-RecA-ATP), the active TLS polymerase. ${ }^{20}$

Until $1998, \mathrm{UmuD}^{\prime}{ }_{2} \mathrm{C}$ was widely considered an auxiliary factor that, with RecA, somehow modulated DNA polymerase III to effect mutagenic DNA synthesis across lesions in the DNA template. However, when incubated in the presence of $\operatorname{RecA}^{*}$, the same $\mathrm{UmuD}_{2}{ }_{2} \mathrm{C}$ promoted TLS in the absence of any added DNA polymerase. ${ }^{13}$ Most notably, pol III holoenzyme (HE) composed of pol III core ( $\alpha \varepsilon \theta$ subunits) $+\beta$ sliding clamp $+\gamma$ clamp loader complex, was absent. ${ }^{13}$ Soon thereafter $\mathrm{UmuD}_{2}{ }_{2} \mathrm{C}$ was identified aspol $\mathrm{V},{ }^{5}$ whose catalytic activity resides in its UmuC subunit. ${ }^{5,6}$ The "auxillary factor" therefore evolved into a bona fide DNA polymerase $;{ }^{8}$ many more have since been identified in prokaryotes and eukaryotes. ${ }^{8,21,22}$

Despite its demonstrable polymerase activity, pol $\mathrm{V}$ was largely catalytically inactive in the absence of RecA* ${ }^{5,13}$ This review is centered on why and how RecA* is needed for pol V activity. Distinct from its role as a coprotease in converting $\mathrm{UmuD} \rightarrow \mathrm{UmuD}^{\prime}, \mathrm{Rec}^{*}$ plays a unique and (for RecA) uncharacteristically direct role in pol $\mathrm{V}$ function. RecA*, acting as a catalyst, transfers a RecA monomer from its $3^{\prime}$-proximal filament tip along with a molecule of ATP, to inactive pol $\mathrm{V}$ to form an activated pol V mutasome, pol V Mut (a complex of UmuD' ${ }_{2} \mathrm{C}$-RecA-ATP). ${ }^{20}$ ATP may either be transferred in concert with RecA or it might perhaps bind separately.

The biochemical roles of RecA and ATP in regulating pol V Mut activity have come into focus since 2009, with surprises at every step. There are limited studies demonstrating the role of RecA outside nucleoprotein filaments, such as its ability to bind to DinB and modulate polymerase fidelity. ${ }^{23,24}$ However, pol V Mut is the only instance where a physical complex with a RecA monomer is absolutely essential for DNA polymerase activity. ${ }^{20}$ Recent advances add to the dynamic. Pol V Mut has an intrinsic DNA-dependent ATPase activity that appears to act as internal clock to regulate polymerase processivity. ${ }^{25}$ The RecA* activation of pol V is spatially regulated, most likely occurring at the cell membrane. ${ }^{26}$ The last observation connects current research with the mid- ' 80 s observation of Evelyn Witkin that RecA* is localized on the membrane in E. coli lysates. ${ }^{27}$ More recently, it has become clear that initiation of the SOS response depends upon that same RecA membrane localization. ${ }^{28}$ The robust field of SOS "error-prone" repair initiated by Witkin ${ }^{29}$ and Miroslav Radman ${ }^{30}$, just keeps on giving, thus providing impetus to reflect on the earlier genetic-based TLS models in light of recent biochemical and live cell imaging discoveries. 


\section{TLS BEFORE 1998}

The Bridges-Woodgate two-step lesion bypass model ${ }^{31}$ involving the UmuDC proteins and RecA (Figure 2A) provides a mechanistic framework to trace the progress in dissecting the biochemical basis of pol V-catalyzed TLS. In the first step, nucleotide misincorporation at the site of DNA damage, pol III copies the lesion, requiring the action of RecA protein. In the second step, lesion bypass, UmuC and UmuD proteins are needed to facilitate continued DNA synthesis on the priming end opposite the lesion. ${ }^{31}$ The importance of the umuDC operon encoded damaged-induced genes for SOS mutagenesis ${ }^{1,2,32}$ was established before the Bridges-Woodgate model was proposed in 1985. Cells having defects in either umuCor umuD are UV non-mutable. ${ }^{1} \mathrm{~A}$ direct role for RecA in pol III-catalyzed misincorporation was assumed in the model based on $\operatorname{rec} A$ mutant strains that exhibited differences in their RecA* coprotease activity; those with good coprotease activity promoted higher levels of mutagenesis, while those with poor coprotease activity promoted low levels of mutagenesis. ${ }^{33}$ Three years later, the discovery that $\mathrm{UmuD}^{\prime}$ was the active form of UmuD, formed by the coproteolytic activity of RecA*, provided an alternative explanation for the role of RecA in SOS mutagenesis. ${ }^{17,18}$ The stage was set for another wrinkle.

Devoret and colleagues ${ }^{34}$ soon demonstrated that RecA* had a separate and direct role in TLS. The RecA S117F mutant, named RecA1730, was able to catalyze homologous recombination, use its coproteolytic function to cleave the LexA repressor to turn on SOS and cleave UmuD to form UmuD'. However, SOS mutagenesis did not occur. This newly discovered direct role for RecA in TLS led to a new mutasome model proposed by Echols \& Goodman ${ }^{35}$ (Figure 2B). Relying on the known filament-forming properties of RecA, the model placed a RecA nucleoprotein filament in cis, at the lesion site on the template strand being copied. It was assumed that this filament would somehow facilitate replication past the lesion with reduced fidelity. This might occur by inhibiting pol III proofreading, ${ }^{36}$ or perhaps by reducing insertion specificity by stretching the ssDNA at the stalled replication fork (Figure 2B). The mutagenically active UmuD' was included in this "Echols mutasome" model. ${ }^{35}$ Thus, although many parts of the model proved incorrect, all of the main actors in the story were finally present. Quoting from our contemporary 1990 review, ${ }^{35}$ "What is the direct role of RecA in mutagenesis? At this point we can make reasonable guesses, but the answer awaits a biochemical reconstitution of translesion replication".

\section{BIOCHEMICAL RECONSTITUTION OF TLS}

In 1989 minuscule amounts of soluble UmuC were obtained by refolding the purified and denatured protein. ${ }^{19}$ Soon after that detectable levels of TLS were generated in a reconstituted system in vitro with UmuC, UmuD', pol III, and RecA. ${ }^{37}$ However, it wasn't until 1998 when a soluble $\mathrm{UmuD}_{2} \mathrm{C}$ complex was isolated ${ }^{13}$ and the biochemical reconstitution of TLS with purified SOS proteins achieved. ${ }^{13,38}$ With the exception of UmuC, the individual components in the sketch of the mutasome model (Figure 2B), RecA*, $\mathrm{UmuD}^{\prime}$, pol III HE were available as purified aqueous soluble proteins. Native UmuC, on the other hand was insoluble in aqueous solution. ${ }^{19}$ Overexpression of UmuC and $\mathrm{UmuD}^{\prime}$ in the absence of chromosomal UmuC and most importantly UmuD allowed the purification ofUmuC and $\mathrm{UmuD}^{\prime}$ as a soluble heterotrimeric complex, $\mathrm{UmuD}_{2}{ }_{2} \mathrm{C} .{ }^{39}$ Parenthetically, 
although not appreciated at the time, it was essential to delete the chromosomal umuD gene to prevent formation of a stable and interfering $\mathrm{UmuD}^{\prime} \mathrm{D}$ complex that triggers the release and precipitation of UmuC. ${ }^{40}$ Consistent with the biochemically recalcitrant nature of UmuC, we now know that, UmuC resides on the cell membrane and only enters the cytosol upon binding to $\mathrm{UmuD}_{2}{ }_{2} \cdot{ }^{26}$

Each of the required SOS mutagenesis protein components identified genetically were now in-hand in a highly purified soluble form: $\mathrm{UmuD}_{2}^{\prime} \mathrm{C}, \mathrm{Rec} \mathrm{A}^{*}$, presumably all acting to somehow alter the activity of pol III HE. These proteins were used to copy primer-template (p/t) DNA containing a site-directed template (abasic) lesion. ${ }^{13,38}$ Robust synthesis on the damaged DNA template ensued. Unexpectedly, TLS occurred in the absence of pol III core. ${ }^{13}$ Indeed, pol III acted as a competitive inhibitor to $\mathrm{UmuD}_{2}{ }_{2} \mathrm{C}$ at the TLS step, ${ }^{13}$ and that was because $\mathrm{UmuD}_{2}^{\prime} \mathrm{C}$ is a DNA polymerase. ${ }^{5,6}$ Examination of this TLS activity opened new questions about the role of RecA. The pol V-catalyzed DNA synthesis was diminished markedly in the absence of $\operatorname{Rec} A * 5,13$. What was $\operatorname{Rec} A *$ doing, and where was it doing it?

\section{TLS 1998 - 2006 RecA* CIS-ACTIVATION}

The elegantly simple 2-step model proposed in 1985 (Figure 2A) provided a focus for research for over twenty years. It was flexible enough to incorporate each new biochemical advance in the period. In the "mutasome" model, ${ }^{35}$ a molecule of RecA was replaced by a RecA* nucleoprotein filament, which was assumed to assemble at a DNA template lesion downstream of a stalled replication fork (Figure 2B). The subsequent identification of $\mathrm{UmuD}_{2} \mathrm{C}$ as a TLS polymerase resulted in a model in which pol III blocked at a lesion (Figure 3, left panel) was replaced on the $\beta$-clamp by pol V (Figure 3, right panel). Although modified to include newly discovered biochemical components, the common thread of each ensuing model remained the location of RecA* on the template strand immediately downstream of, and perhaps even encompassing the lesion (Figure 3). This has been defined as the cis-activation model for TLS, because RecA* is presumed to act in cis on the strand being copied to shepherd a stalled polymerase past the lesion. ${ }^{41-43}$

Figure 3 illustrates individual steps in TLS via cis-activation by RecA*. Initially, an advancing replication fork containing pol III HE becomes stalled at a lesion. Leading- and lagging-strand replication become uncoupled. Continued unwinding of dsDNA ahead of the blocked fork by the DnaB helicase results in a region of ssDNA downstream of the lesion on which RecA* can assemble (Figure 3, left panel). Pol Vreplaces pol III core on the $\beta$ clamp and performs TLS accompanied presumably by progressive and concurrent $3^{\prime} \rightarrow 5^{\prime}$ disassembly of RecA*. ${ }^{41}$ Following TLS, pol III core would replace pol V to resume rapid DNA synthesis on undamaged DNA downstream from the lesion (Figure 3, right panel).

Given the formation and requirement for RecA* nucleoprotein filaments, cis-activation models seemed intuitively obvious to many investigators, including us. If RecA* is required for TLS, its location should be in the single-strand DNA gap at the lesion, where it can interact with pol V. However, this construct had multiple problems. While one could visualize how the presence of RecA* might stimulate lesion bypass by interacting with pol 
III core, e.g., perhaps by inhibiting $\varepsilon$ exonuclease proofreading, there was no obvious biochemical rationale for the workings of RecA* in conjunction with pol V. A RecA* filament on the DNA is a potentially formidable barrier to the progress of any DNA polymerase. The model envisioned displacement of RecA subunits at the RecA filament end where filament growth normally predominates. ${ }^{44-50}$ Active RecA filament displacement from this filament end was proposed as a part of a model, where pol $\mathrm{V}$ was dubbed a "cowcatcher". 41 The DNA synthesis observed seemed to require such a displacement, but was not directly demonstrated as an activity of pol V. The subsequent demonstration of trans-activation of pol $\mathrm{V}^{51}$ provided an explanation of the pol V-mediated DNA synthesis results without invoking RecA displacement in cis. Currently, direct RecA displacement function has been demonstrated only for specialized helicases such as $\mathrm{UvrD}^{52}$ and PcrA. 53,54

\section{TLS AFTER 2006 RecA* TRANS-ACTIVATION}

The cis-activation construct began to give way in $2006 .^{51}$ When pol V was used to copy $\mathrm{p} / \mathrm{t}$ DNA in the form of a hairpin, containing a very short 3-nt template overhang (Figure 4), replication of the short template by pol $\mathrm{V}$ required the presence of RecA* assembled on a separate ssDNA molecule acting in trans (Figure 4). The new trans protocol also increased the overall efficiency of primer utilization dramatically and consistently. Apparently, assembling the RecA* filament in cis had constrained reaction efficiency in many experiments. ${ }^{55,56}$ The fraction of p/t DNA extended by pol V was directly proportional to the concentration of trans $\operatorname{Rec} A^{*}$ in accord with $2^{\text {nd }}$ order kinetics. ${ }^{51}$ The 3 nt template cannot support the assembly of a cis-RecA* filament (at least one that is restricted to the ssDNA region) because the footprint of a single RecA molecule is itself $3 \mathrm{nt}$. How might a transactivated pol V Mut behave were it to encounter RecA* assembled downstream of a lesion? The presence of RecA* acts as a block to DNA synthesis and would presumably need to be displaced, which could involve SSB, as proposed in our previous "cowcatcher" model for TLS, ${ }^{41}$ or perhaps more likely by the $\mathrm{UvrD}^{52}$ or PcrA ${ }^{53,54}$ helicases.

The pol V trans-activation method offered a straightforward approach to determine the molecular basis for the enigmatic requirement for RecA* during TLS. By locating pol V and RecA* on separate macromolecules, one had only to mix the pol V together with transRecA* and ask: what happens? To answer this question it was necessary to completely separate the trans-RecA* from pol V following incubation, to eliminate any possibility of continued transactivation of pol V. Quantitative separation was achieved by forming RecA* filaments on ssDNA that was covalently linked to streptavidin-coated agarose beads, spinning the beads out of solution to remove the trans-RecA*, and isolating a putative modified form of pol $\mathrm{V}$ from the supernatant(Figure 5). ${ }^{20}$

\section{RecA $^{*}$ - Pol V Transactivation Mechanism}

When pol V (UmuD $\left.{ }_{2} \mathrm{C}\right)$ was exposed toRecA* in trans, a molecule of RecA accompanied by an ATP molecule was transferred from the $3^{\prime}$-proximal tip of the RecA nucleoprotein filament to form an active mutasomal complex, now referred to as pol V Mut. The final activated pol V Mut complex is $\mathrm{UmuD}_{2}{ }_{2} \mathrm{C}-\mathrm{RecA}_{-} \mathrm{ATP}^{20}$ (Figure 5). The transfer of RecA to 
pol V was revealed using MALS (Multi Angle Light Scattering). ${ }^{20}$ This powerful technique provides an absolute measurement of molecular mass. ${ }^{57} \mathrm{UmuD}_{2}{ }_{2} \mathrm{C}(72 \mathrm{kDa})-\mathrm{RecA}(38 \mathrm{kDa})$ has a predicted molecular mass of $110 \mathrm{kDa}$, in excellent agreement with $113 \mathrm{kDa}$ obtained with MALS. Pol V in the absence of bound RecA has a molecular mass of $73 \mathrm{kDa}$ in close agreement with its predicted value. A PAGE analysis verified that RecA was present in the light scattering peak corresponding to pol $\mathrm{V}$ Mut, but absent in the pol $\mathrm{V}$ peak.

\section{Pol V Mut Copies DNA in the Absence of RecA*}

The identification of active pol V Mut as a stand-alone polymerase meant that undamaged and damaged DNA could, for the first time, be replicated efficiently in the absence of RecA*. In order to form pol V Mut, there are stringent spatial restrictions on the RecA*-pol $\mathrm{V}$ interaction. The key amino acids involved in the productive transfer of RecA to pol $\mathrm{V}$ include RecA residues 112 - 117; these are located at the solvent exposed surface near the $3^{\prime}$-tip of RecA*, in close proximity to UmuC(e.g., N113 forms a crosslink with UmuC). ${ }^{58} \mathrm{~A}$ D112R mutation causes a 4-fold reduction in activity, and a D112R/N113R double mutant abolishes polymerase activity. Most importantly, from a historical perspective, pol V Mut assembled with Devoret's SOS non-mutable RecA mutant, $\mathrm{UmuD}_{2}{ }_{2} \mathrm{C}-\operatorname{RecA}(\mathrm{S} 117 \mathrm{~F}),{ }^{34}$ is catalytically dead, ${ }^{20}$ thus most likely accounting for the absence of damage induced mutagenesis in RecA1730 (S117F) mutant cells in vivo. ${ }^{34}$ In addition, the RecA surface represented by residues 112-117 is the site of mutations that relieve inhibition of RecAmediated recombination by overexpressed UmuC and UmuD proteins. ${ }^{59}$

The RecA subunit of activated pol V Mut must come from the 3'-proximal end of the RecA* filament. Although a molecule of RecA can also be transferred from the $5^{\prime}$-proximal filament tip to $\mathrm{UmuD}^{\prime}{ }_{2} \mathrm{C}$, that complex lacks detectable polymerase activity. ${ }^{20} \mathrm{~A}$ stable complex can also be formed between $\operatorname{Rec} A$ and $\mathrm{UmuD}^{\prime}{ }_{2} \mathrm{C}$ in the absence of RecA*, but this form of $\mathrm{UmuD}_{2}{ }_{2} \mathrm{C}-\mathrm{Rec} \mathrm{A}$ has no detectable polymerase activity in the presence or absence of ATP. ${ }^{20,60}$ Thus, although RecA* is required to turn on the SOS regulon (Figure 1) and convert $\mathrm{UmuD} \rightarrow \mathrm{UmuD}^{\prime}$ to form pol $\mathrm{V}=\mathrm{UmuD}_{2}{ }_{2} \mathrm{C}$, the precursor form of pol $\mathrm{V}$ Mut (Figure 1), the most direct role of RecA* during SOS mutagenesis resides in the formation of a functional pol V Mut by transferring a RecA subunit to pol V.

\section{Pol V Mut Requires Bound ATP $\gamma$ S/ATP}

Pol V Mut assembles in 1:2:1:1 stoichiometry with UmuC, UmuD', RecA, and ATP/ ATP $\gamma \mathrm{S} .{ }^{20}$ The transfer of one molecule of RecA from the 3'-proximal tip of RecA* to $\mathrm{UmuD}^{\prime}{ }_{2} \mathrm{C}$ occurred concomitantly with the binding of one molecule of ATP $\gamma \mathrm{S} .{ }^{20} \mathrm{This}$ slowly hydrolyzing nucleotide cofactor ensures stable RecA* filament assembly, since filaments formed with ATP undergo a dynamic assembly-disassembly process resulting from ATP hydrolysis. ${ }^{46,61,62}$ However in the original transactivation assays, the stoichiometric binding of $\mathrm{ATP} \gamma \mathrm{S}$ to $\mathrm{UmuD}_{2}{ }_{2} \mathrm{C}$ had actually taken place adventitiously from the supernatant containing pol V Mut (Figure 5), and not directly during the transfer of RecA. ${ }^{25}$ The role of the nucleotide cofactor in the pol V Mut complex, if any, was not understood at that time.

A more efficient transactivation protocol was developed, utilizing cyanogen-bromide Sepharose beads with RecA* bound to covalently attached ssDNA in the presence of 
ATP $\gamma \mathrm{S}$, along with the use of spin column to separate pol V Mut from the trans-RecA*, unbound RecA, as well as the free ATP $\gamma$ S/ATP used to form RecA*. ${ }^{25}$ We recovered a form of pol V Mut (UmuD' $\left.{ }_{2} \mathrm{C}-\mathrm{Rec} \mathrm{A}\right)$ devoid of both ATP $\gamma \mathrm{S} / \mathrm{ATP}$ and polymerase activity. ${ }^{25}$ Restoration of pol V Mut activity occurred upon addition of new ATP $\gamma$ S/ATP. Therefore, an adenosine nucleoside triphosphate cofactor ATP, dATP or ATP $\gamma \mathrm{S}$ was necessary as an integral component of pol V Mut to catalyze DNA synthesis on undamaged and damaged (TLS) DNA templates. Other nucleotide forms are unable to substitute for ATP $\gamma \mathrm{S}$ or ATP, e.g., pol V Mut is not activated by GTP, ADP or dTTP. ${ }^{25}$

\section{POL V MUT IS A DNA-DEPENDENT ATPASE}

The molecular basis for the A nucleotide cofactor requirement was soon revealed. Pol V Mut cannot bind to a DNA primer-3'-end, and hence has no polymerase activity, unless a molecule of ATP $\gamma$ S/ATP is present in the complex. ${ }^{25}$ More remarkable, pol V Mut has an intrinsic DNA-dependent ATPase activity ${ }^{25}$ This activity is distinct from the canonical DNA-dependent ATPase of RecA*. Pol V Mut retains its ATPase activity when assembled using a mutant RecA* (RecAK72R), which essentially eliminates RecA*-dependent ATPase activity. $25,63,64$

Playing the reciprocal role for ATP in binding to p/t DNA, the ATPase is required to release pol V Mut from a primer- $3^{\prime}$-end. There is a very close correspondence of ATP hydrolysis rate $\left(54 \pm 9 \times 10^{-3} \mathrm{~s}^{-1}\right)$ to the first order pol V Mut-p/t DNA release rate $\left(53 \pm 2.5 \times 10^{-3}\right.$ $\mathrm{s}^{-1}$ ), strongly suggesting that the hydrolysis of one ATP molecule triggers the release of pol V Mut from p/t DNA. ${ }^{25}$ In contrast, pol V Mut remains stably bound to DNA in the presence of ATP $\gamma \mathrm{S}$ where hydrolysis does not occur. ${ }^{25}$ The DNA-dependent ATPase can be viewed as an internal clock that limits pol V Mut processivity so as to minimize the occurrence of mutations on undamaged DNA following TLS. The individual steps in the ATP-ATPase regulation of pol V Mut activity are shown in Figure 6.

\section{SPATIAL REGULATION OF POL V MUT ACTIVATION IN VIVO}

The activity of pol V Mut is clearly regulated on many levels. Formation of the enzyme requires an elaborate activation process with multiple steps. The lifetime of the active complex on DNA is regulated by an intrinsic ATPase activity. ${ }^{25}$ But this is not the end of the regulation story. Yet another level of regulation of pol V Mut, this one spatial, has recently been revealed in living cells by fluorescence imaging at single-molecule ( $\mathrm{sm}$ ) resolution. ${ }^{26}$ This study addressed the cellular location of pol V Mut after induction of the SOS regulon. Replacement of wild-type umuC with fluorescently labeled umuC-mKate 2 showed that UmuC is synthesized and localized at the inner cell membrane $\sim 45 \mathrm{~min}$ after UV irradiation. Thereafter, UmuC remains sequestered on the membrane and is released into the cytosol only after RecA*-mediated UmuD $\rightarrow \mathrm{UmuD}^{\prime}$ cleavage occurs. The membrane association explains why UmuC is inherently insoluble in aqueous solution and is solubilized by binding with $\mathrm{UmuD}_{2}{ }_{2}^{39}$ to form pol V. ${ }^{5,13}$ In accord with the biochemical data, live-cell imaging shows that UmuC stays bound to the membrane in a non-cleavable umuD(K97A $)^{9}$ mutant strain that cannot form $\mathrm{UmuD}^{\prime}$. The fluorescently labeled pol V Mut (UmuC-mKate2) is partially functional in the cell, promoting increased DNA damage 
induced spontaneous mutagenesis. ${ }^{26}$ Therole of the membrane in the activation mechanism of pol V, as now understood, is shown in Figure 7. Most of the current information centers on the membrane sequestration of UmuC prior to its incorporation into active complexes. RecA protein is also present in the membrane, ${ }^{27,28}$ but it is not clear if that RecA is in a form that can activate pol $\mathrm{V}$. It is possible that UmuC is removed from the membrane by association with $\mathrm{UmuD}_{2}{ }_{2}$ and later activated to functional pol $\mathrm{V}$ Mut after diffusion and interaction with RecA* bound to the bacterial chromosome. It is also possible that additional steps occur at the membrane, such as UmuD cleavage and activation to pol V Mut, involving currently unknown functions of membrane-associated RecA protein.

Once active pol V Mut is formed, where does it go? Instead of a complex activated at the site of a lesion, we now see a freely diffusible activated pol V Mut complex. In principle, it could act at a stalled replication fork, or in a single strand and lesion-containing gap left behind after restart of that stalled fork. ${ }^{65}$ Following the release of pol V into the cytosol, the co-localization of pol $\mathrm{V}$ mutasomes with replication forks depends on the RecA variant that is present ${ }^{26}$. When pol V Mut contains wild type RecA, i.e., UmuD' ${ }_{2} \mathrm{C}-\mathrm{Rec}_{\mathrm{WT}} \mathrm{ATP}$, there is no co-localization between pol V Mut and pol III HE above what would be predicted if the two species were located randomly throughout the cell $(\sim 5 \%) .{ }^{26}$ The absence of colocalization between pol V Mut and pol III HE in replication foci suggests that either the polymerases form a very transient ternary complex, with pol V Mut bound for $<30 \mathrm{~ms}$ (the imaging rate used was $30 \mathrm{~Hz}$ and there were no indications of transient focus formation), or that the presumed exchange of the high fidelity pol III HE blocked at a DNA damage site with the low fidelity pol V Mut to permit TLS may in fact not be occurring. The result brings into question the widely held view that mass-action binding of pol $\mathrm{V}$ occurs uniquely at stalled replication forks. Instead, when pol III skips over a replication-blocking lesion and initiates DNA synthesis downstream, a $\beta$-clamp may be left at the lesion site to which pol V Mut can bind and catalyze TLS. Our in vivo observation comports with the pol III lesionskipping model proposed by Yeeles and Marians ${ }^{65}$ based on biochemical data showing that when impeded by DNA damage, pol III jumps past the damage site leaving behind a $\beta$ clamp bound to a 3 '-primer end. The polymerase then reinitiates synthesis on the same template strand downstream from the lesion on a re-loaded $\beta$ clamp using an RNA primer formed by DnaG primase. ${ }^{66,67}$

In contrast to the behavior observed in cells with wild type RecA, a significant proportion of pol V Mut foci $(27 \pm 3 \%)$ co-localize with pol III HE in cells containing the constitutively expressed RecA E38K mutant (previously referred to as RecA730). ${ }^{27}$ These data suggest that pol V can replace pol III during normal DNA synthesis on undamaged templates. Constitutively expressed in undamaged cells, RecA E38K will activate pol V in an environment where lesion-containing gaps are less common. Its subsequent action at replication forks may help explain the 100-fold increase in pol V Mut-catalyzed SOS mutagenesis in the absence of exogenous DNA damage observed in cells constitutively induced for RecA E38K. ${ }^{10}$ When copying undamaged DNA, the fidelity of proofreadingdeficient pol V Mut, deoxynucleotide misincorporation, $\sim 10^{-2}-10^{-3}, 4$ is typically more than a thousand-fold lower than that of proofreading proficient pol III HE. ${ }^{68}$ 


\section{SOS MUTAGENESIS MODEL 2015}

We suggest a unified model for the regulation of SOS mutagenesis that integrates the original in vivo genetic-based concepts to in vitro biochemical data obtained since 2009, with current live-cell imaging microscopy that furnishes essential physiological missing links coupling the old genetics and new biochemistry. The model is divided into three distinct mechanistic stages. Stage 1 embodies numerous genetic studies showing that $u m u D C$ is transcribed as a late SOS function (Figure 1). Stage 2portrays combined genetic and biochemical studies depicting the temporally retarded RecA*-mediated cleavage of $\mathrm{UmuD} \rightarrow \mathrm{UmuD}^{\prime}$, required for SOS mutagenesis (Figure 7), and the identification of the activated form of pol $\mathrm{V}\left(\mathrm{UmuD}_{2}{ }_{2} \mathrm{C}\right)$ as pol V Mut $\left(\mathrm{UmuD}^{\prime}{ }_{2} \mathrm{C}\right.$-RecA-ATP) (Figure 5). The individual biochemical steps to convert pol $\mathrm{V}$ to activated pol $\mathrm{V}$ Mut are presented in Figure 6. Stage 3 illustrates how ATP and ATP hydrolysis regulate pol V Mut activity. The steps for ATP activation and ATPase deactivation of pol V Mut are shown in Figure 6. This $3^{\text {rd }}$ stage describing a unique internal regulation mechanism governing pol V Mut activity, presumably limits error-prone DNA synthesis to include TLS and short regions of undamaged DNA in the vicinity of a damaged template base. The mutational load associated with pol $\mathrm{V}$ is thus minimized.

When it was discovered that pol V could be activated by RecA* acting in trans (Figure 4) and didn'tneed to be located on ssDNA proximal to a DNA damage site being copied (see, e.g., Figure 3), the question of cellular location of these events had no obvious answer. Things became a bit easier to explain when the molecular mechanisms of RecA* transactivation was established (Figure 5). A stand-alone form of pol $\mathrm{V}$ was identified that, once formed, works in the absence RecA*(Figure 6). Yet the salient question remained, if not activated by RecA* at a blocked replication fork as originally proposed (Figures 2 and 3 ), then where in the cell did pol $\mathrm{V}$ encounter a transactivating RecA* nuclear protein filament? At the cell membrane seems likely to be the answer based on the recent live cell imaging studies, ${ }^{26}$ thus providing a directly visualized missing link between the old genetics, ${ }^{27}$ new biochemistry, ${ }^{26,28}$ and cell physiology.

\section{A MYOPIC LOOK BEYOND 2016}

Given the many unforeseeable twists encountered in the story of this system to date, any look ahead is a bit adventurous. Akin to a toggle switch, pol V Mut turns on and off repeatedly with RecA staying bound when in activated and deactivated states(Figure 6B). ${ }^{20}$ Activated pol V Mut (Figure 6A) can perform limited numbers of DNA synthesis cycles before it deactivates (Figure 6B). If needed, deactivated pol V Mut can be reactivated by fresh RecA* that exchanges an "old" RecA monomer for a new one, but presumably in a different position in relation to UmuC. ${ }^{58}$ When SOS is dialed down, a reduced availability of RecA* would presumably ensure that the deactivated form of pol V Mut is unlikely to be reactivated.

The location ofRecA in relation to UmuC in activated and deactivated conformations is the next issue to resolve. The dynamics of RecA-UmuC switching could be visualized at singlemolecule resolution, in real time, using TIRF-FRET microscopy, provided that a dual- 
labeled pol V Mut (e.g., Cy3-UmuC, Cy5-RecA) remains active. Upon a first stab at aminoacid crosslinking, tandem mass spec analysis found that contacts between RecA and UmuC differed significantly in active and inactive forms of pol V Mut. ${ }^{58} \mathrm{~A}$ high-resolution crystal structure for even just one of the two pol V Muts, live or dead, would prove invaluable. Parenthetically, however, despite the rapid advances in cryo EM, pol V Mut (110 kDa) is currently too small to be resolved.

Pol V Mut's intrinsic ATPase appears unique, lacking Walker A or B motifs. RecA*'s ATPase seems not germane because pol V Mut assembled with an ATPase-deficient RecA K72R mutant, pol V Mut E38K/K72R, has an avid DNA-dependent ATPase. ${ }^{25}$ Thus, a current challenge is to identify the interacting surfaces between $\operatorname{RecA}$ and $\mathrm{UmuD}_{2}^{\prime} \mathrm{C}$ that form this potentially new type of hybrid ATPase active site. Recently, we have used desthobiotin-ATP crosslinking ${ }^{69}$ and tandem mass spectrometry to identify a lysine residue in UmuC (K403) that contributes to ATP binding-initiated DNA synthesis and to ATPase activity. This is admittedly a small beginning.

Apart from TLS, pol V Mut has an existential role in bacterial fitness and evolution, as do its two companion SOS-induced pols II and IV (Figure 1). ${ }^{70,71}$ Pols II and IV are present at high constitutive levels (50 and 400 molecules/cell, respectively) in the absence of external stressors, whereas pol V Mut is present at no more than about 10 molecules per cell. ${ }^{26,72}$ Yet each contributes to about the same extent in ensuring cell survival by generating lifesustaining mutations, with different spectral signatures. ${ }^{70,71}$ The cell survival data using all possible combinations of SOS polymerase genetic backgrounds suggests that pol II works most effectively during exponential growth, with pols $\mathrm{V}$ and IV taking over to maximize fitness in stationary and deep-stationary phases. ${ }^{70,71}$ Live-cell imaging is ideally suited to visualize when and under what conditions (e.g., \pm UV) any of the SOS polymerases colocalize with pol III, and further to determine whether the presence or absence of each SOS polymerase alters the competition for binding to DNA. The power of the live-cell imaging techniques comes into full play here because individual cells can be studied as part of an ensemble of cells. Here, as before, live cell imaging can provide a missing link between genetics, biochemistry and cell physiology.

\section{Acknowledgments}

Funding Sources

This work was supported by National Institute of Health grants to MFG (ES012259; GM21422) and to MMC (GM32335); funds from the Eunice Kennedy Shriver National Institute of Child Health and Human Development/ National Institutes of Health Intramural Research Program to RW; funds from the Netherlands Organization for Scientific Research (NWO; Vici 680-47-607) and the European Research Council (ERC Starting 281098) to AvO.

Our sincere gratitude to the founders of the long-lived field of damage-induced regulation of DNA repair and SOS mutagenesis, Jean Weigle, Evelyn Witkin, Miro Radman, Bryn Bridges, Raymond Devoret, Graham Walker on the genetics principles, Hatch Echols, on the biochemical principles. Our later collaborators, Menjia Tang for developing the first robust TLS assay and identifying $\mathrm{UmuD}_{2}^{\prime} \mathrm{C}$ as a new, error-prone DNA polymerase; Phuong Pham, for our early biochemical TLS studies; Kathi Schlacher for discovering RecA* transactivation; Kiyonobu Karata, for developing a large-scale expression system and rapid purification for pol V; Fay Jiang for identifying pol V Mut; Aysen Erdem, for identifying the intrinsic pol V Mut ATPase; and Liz Wood for implementing chromosomal replacement strategies to study live cell imaging of fluorescent UmuC. 


\section{ABBREVIATIONS}

$\begin{array}{ll}\text { UV } & \text { ultraviolet light } \\ \text { SSDNA } & \text { single-stranded DNA } \\ \text { TLS } & \text { Translesion Synthesis } \\ \text { nt } & \text { nucleotide } \\ \text { DNA pol V } & \text { DNA polymerase V } \\ \text { pol V Mut } & \text { polymerase V Mutasome } \\ \text { pol III HE } & \text { polymerase III holoenzyme } \\ \text { ATP } & \text { Adenosine triphosphate } \\ \text { ATP } \gamma & \text { Adenosine 5'-(3-thiotriphosphate) tetralithium salt } \\ \text { RecA* } & \text { RecA nucleoprotein filament } \\ \text { kDa } & \text { kilodalton } \\ \text { MALS } & \text { Multiangle Light Scattering } \\ \text { PAGE } & \text { polyacrylamide gel electrophoresis } \\ \text { sm } & \text { single-molecule } \\ \text { TIRF } & \text { Total internal reflection fluorescence } \\ \text { FRET } & \text { Förster resonance energy transfer }\end{array}$

\section{REFERENCES}

1. Kato T, Shinoura Y. Isolation and characterization of mutants of Escherichia coli deficient in induction of mutations by ultraviolet light. Mol Gen Genet. 1977; 156:121-131. [PubMed: 340898]

2. Steinborn G. Uvm mutants of Escherichia coli K12 deficient in UV mutagenesis. I. Isolation of uvm mutants and their phenotypical characterization in DNA repair and mutagenesis. Mol Gen Genet. 1978; 165:87-93. [PubMed: 362169]

3. Woodgate R, Sedgwick SG. Mutagenesis induced by bacterial UmuDC proteins and their plasmid homologues. Mol Microbiol. 1992; 6:2213-2218. [PubMed: 1406263]

4. Tang M, Pham P, Shen X, Taylor JS, O'Donnell M, Woodgate R, Goodman MF. Roles of E. coli DNA polymerases IV and V in lesion-targeted and untargeted SOS mutagenesis. Nature. 2000; 404:1014-1018. [PubMed: 10801133]

5. Tang M, Shen X, Frank EG, O'Donnell M, Woodgate R, Goodman MF. UmuD'(2)C is an errorprone DNA polymerase, Escherichia coli pol V. Proc Natl Acad Sci U S A. 1999; 96:8919-8924. [PubMed: 10430871]

6. Reuven NB, Arad G, Maor-Shoshani A, Livneh Z. The mutagenesis protein UmuC is a DNA polymerase activated by UmuD', RecA, and SSB and is specialized for translesion replication. $\mathbf{J}$ Biol Chem. 1999; 274:31763-31766. [PubMed: 10542196]

7. Wagner J, Gruz P, Kim SR, Yamada M, Matsui K, Fuchs RP, Nohmi T. The dinB gene encodes a novel E. coli DNA polymerase, DNA pol IV, involved in mutagenesis. Mol Cell. 1999; 4:281-286. [PubMed: 10488344]

8. Ohmori H, Friedberg EC, Fuchs RP, Goodman MF, Hanaoka F, Hinkle D, Kunkel TA, Lawrence CW, Livneh Z, Nohmi T, Prakash L, Prakash S, Todo T, Walker GC, Wang Z, Woodgate R. The Yfamily of DNA polymerases. Mol Cell. 2001; 8:7-8. [PubMed: 11515498] 
9. Nohmi T, Battista JR, Dodson LA, Walker GC. RecA-mediated cleavage activates UmuD for mutagenesis: mechanistic relationship between transcriptional derepression and posttranslational activation. Proc Natl Acad Sci U S A. 1988; 85:1816-1820. [PubMed: 3279418]

10. Sweasy JB, Witkin EM, Sinha N, Roegner-Maniscalco V. RecA protein of Escherichia coli has a third essential role in SOS mutator activity. J Bacteriol. 1990; 172:3030-3036. [PubMed: 2188949]

11. Sato N, Ohnishi T, Tano K, Yamamoto K, Nozu K. Induction of umuC+ gene expression in Escherichia coli irradiated by near ultraviolet light. Photochem Photobiol. 1985; 42:135-139. [PubMed: 3931110]

12. Frank EG, Ennis DG, Gonzalez M, Levine AS, Woodgate R. Regulation of SOS mutagenesis by proteolysis. Proc Natl Acad Sci U S A. 1996; 93:10291-10296. [PubMed: 8816793]

13. Tang M, Bruck I, Eritja R, Turner J, Frank EG, Woodgate R, O'Donnell M, Goodman MF. Biochemical basis of SOS-induced mutagenesis in Escherichia coli : reconstitution of in vitro lesion bypass dependent on the UmuD' 2 C mutagenic complex and RecA protein. Proc Natl Acad Sci U S A. 1998; 95:9755-9760. [PubMed: 9707548]

14. Gon S, Napolitano R, Rocha W, Coulon S, Fuchs RP. Increase in dNTP pool size during the DNA damage response plays a key role in spontaneous and induced-mutagenesis in Escherichia coli. Proc Natl Acad Sci U S A. 2011; 108:19311-19316. [PubMed: 22084087]

15. Kuzminov A. Recombinational repair of DNA damage in Escherichia coli and bacteriophage lambda. Microbiol Mol Biol Rev. 1999; 63:751-813. table of contents. [PubMed: 10585965]

16. Little JW. Autodigestion of lexA and phage lambda repressors. Proc Natl Acad Sci U S A. 1984; 81:1375-1379. [PubMed: 6231641]

17. Shinagawa H, Iwasaki H, Kato T, Nakata A. RecA protein-dependent cleavage of UmuD protein and SOS mutagenesis. Proc Natl Acad Sci U S A. 1988; 85:1806-1810. [PubMed: 3126496]

18. Burckhardt SE, Woodgate R, Scheuermann RH, Echols H. UmuD mutagenesis protein of Escherichia coli : overproduction, purification, and cleavage by RecA. Proc Natl Acad Sci U S A. 1988; 85:1811-1815. [PubMed: 3279417]

19. Woodgate R, Rajagopalan M, Lu C, Echols H. UmuC mutagenesis protein of Escherichia coli: purification and interaction with UmuD and UmuD'. Proc Natl Acad Sci U S A. 1989; 86:73017305. [PubMed: 2552436]

20. Jiang Q, Karata K, Woodgate R, Cox MM, Goodman MF. The active form of DNA polymerase V is UmuD'(2)C-RecA-ATP. Nature. 2009; 460:359-363. [PubMed: 19606142]

21. Sale JE, Lehmann AR, Woodgate R. Y-family DNA polymerases and their role in tolerance of cellular DNA damage. Nat Rev Mol Cell Biol. 2012; 13:141-152. [PubMed: 22358330]

22. Goodman MF, Woodgate R. Translesion DNA polymerases. Cold Spring Harb Perspect Biol. 2013; 5:a010363. [PubMed: 23838442]

23. Godoy VG, Jarosz DF, Simon SM, Abyzov A, Ilyin V, Walker GC. UmuD and RecA directly modulate the mutagenic potential of the Y family DNA polymerase DinB. Mol Cell. 2007; 28:1058-1070. [PubMed: 18158902]

24. Cafarelli TM, Rands TJ, Godoy VG. The DinB*RecA complex of Escherichia coli mediates an efficient and high-fidelity response to ubiquitous alkylation lesions. Environ Mol Mutagen. 2014; 55:92-102. [PubMed: 24243543]

25. Erdem AL, Jaszczur M, Bertram JG, Woodgate R, Cox MM, Goodman MF. DNA polymerase V activity is autoregulated by a novel intrinsic DNA-dependent ATPase. Elife. 2014; 3:e02384. [PubMed: 24843026]

26. Robinson A, McDonald JP, Caldas VE, Patel M, Wood EA, Punter CM, Ghodke H, Cox MM, Woodgate R, Goodman MF, van Oijen AM. Regulation of mutagenic DNA polymerase V activation in space and time. PLoS Genet. 2015; 11:e1005482. [PubMed: 26317348]

27. Garvey N, St John AC, Witkin EM. Evidence for RecA protein association with the cell membrane and for changes in the levels of major outer membrane proteins in SOS-induced Escherichia coli cells. J Bacteriol. 1985; 163:870-876. [PubMed: 3897198]

28. Rajendram M, Zhang L, Reynolds BJ, Auer GK, Tuson HH, Ngo KV, Cox MM, Yethiraj A, Cui Q, Weibel DB. Anionic phospholipids stabilize RecA filament bundles in Escherichia coli. Mol Cell. 2015; 60:374-384. [PubMed: 26481664] 
29. Witkin EM. The radiation sensitivity of Escherichia coli B: a hypothesis relating filament formation and prophage induction. Proc Natl Acad Sci U S A. 1967; 57:1275-1279. [PubMed: 5341236]

30. Radman, M. Phenomenology of an inducible mutagenic DNA repair pathway in Escherichia coli: SOS repair hypothesis. In: Prakash, L.; S, F.; Miller, MW.; Lawrence, CW.; Tabor, HW., editors. In Molecular and environmental aspects of mutagenesis. Springfield, Ill: Charles C. Thomas; 1974. p. 128-142.

31. Bridges BA, Woodgate R. The two-step model of bacterial UV mutagenesis. Mutat Res. 1985; 150:133-139. [PubMed: 4000157]

32. Bagg A, Kenyon CJ, Walker GC. Inducibility of a gene product required for UV and chemical mutagenesis in Escherichia coli. Proc Natl Acad Sci U S A. 1981; 78:5749-5753. [PubMed: 7029544]

33. Bridges BA, Woodgate R. Mutagenic repair in Escherichia coli: products of the recA gene and of the $u m u D$ and $u m u C$ genes act at different steps in UV-induced mutagenesis. Proc Natl Acad Sci U S A. 1985; 82:4193-4197. [PubMed: 3889923]

34. Dutreix M, Moreau PL, Bailone A, Galibert F, Battista JR, Walker GC, Devoret R. New recA mutations that dissociate the various RecA protein activities in Escherichia coli provide evidence for an additional role for RecA protein in UV mutagenesis. J Bacteriol. 1989; 171:2415-2423. [PubMed: 2651400]

35. Echols H, Goodman MF. Mutation induced by DNA damage: a many protein affair. Mutat Res. 1990; 236:301-311. [PubMed: 2169028]

36. Fersht AR, Knill-Jones JW. Contribution of 3' leads to 5' exonuclease activity of DNA polymerase III holoenzyme from Escherichia coli to specificity. J Mol Biol. 1983; 165:669-682. [PubMed: 6222198]

37. Rajagopalan M, Lu C, Woodgate R, O'Donnell M, Goodman MF, Echols H. Activity of the purified mutagenesis proteins UmuC, UmuD', and RecA in replicative bypass of an abasic DNA lesion by DNA polymerase III. Proc Natl Acad Sci U S A. 1992; 89:10777-10781. [PubMed: 1438275]

38. Reuven NB, Tomer G, Livneh Z. The mutagenesis proteins UmuD' and UmuC prevent lethal frameshifts while increasing base substitution mutations. Mol Cell. 1998; 2:191-199. [PubMed: 9734356]

39. Bruck I, Woodgate R, McEntee K, Goodman MF. Purification of a soluble UmuD'C complex from Escherichia coli Cooperative binding of UmuD'C to single-stranded DNA. J Biol Chem. 1996; 271:10767-10774. [PubMed: 8631887]

40. Shen X, Woodgate R, Goodman MF. Escherichia coli DNA polymerase V subunit exchange: a post-SOS mechanism to curtail error-prone DNA synthesis. J Biol Chem. 2003; 278:52546-52550. [PubMed: 14573598]

41. Pham P, Bertram JG, O'Donnell M, Woodgate R, Goodman MF. A model for SOS-lesion-targeted mutations in Escherichia coli. Nature. 2001; 409:366-370. [PubMed: 11201748]

42. Fujii S, Gasser V, Fuchs RP. The biochemical requirements of DNA polymerase V-mediated translesion synthesis revisited. J Mol Biol. 2004; 341:405-417. [PubMed: 15276832]

43. Maor-Shoshani A, Reuven NB, Tomer G, Livneh Z. Highly mutagenic replication by DNA polymerase V (UmuC) provides a mechanistic basis for SOS untargeted mutagenesis. Proc Natl Acad Sci U S A. 2000; 97:565-570. [PubMed: 10639119]

44. Bork JM, Cox MM, Inman RB. RecA protein filaments disassemble in the 5' to 3 ' direction on single-stranded DNA. J Biol Chem. 2001; 276:45740-45743. [PubMed: 11574550]

45. Cox JM, Tsodikov OV, Cox MM. Organized unidirectional waves of ATP hydrolysis within a RecA filament. PLoS Biol. 2005; 3:e52. [PubMed: 15719060]

46. Register JC 3rd, Griffith J. The direction of RecA protein assembly onto single strand DNA is the same as the direction of strand assimilation during strand exchange. J Biol Chem. 1985; 260:12308-12312. [PubMed: 3900072]

47. Shan Q, Bork JM, Webb BL, Inman RB, Cox MM. RecA protein filaments: end-dependent dissociation from ssDNA and stabilization by RecO and RecR proteins. J Mol Biol. 1997; 265:519-540. [PubMed: 9048946] 
48. Arenson TA, Tsodikov OV, Cox MM. Quantitative analysis of the kinetics of end-dependent disassembly of RecA filaments from ssDNA. J Mol Biol. 1999; 288:391-401. [PubMed: 10329149]

49. Bell JC, Plank JL, Dombrowski CC, Kowalczykowski SC. Direct imaging of RecA nucleation and growth on single molecules of SSB-coated ssDNA. Nature. 2012; 491:274-278. [PubMed: 23103864]

50. Joo C, McKinney SA, Nakamura M, Rasnik I, Myong S, Ha T. Real-time observation of RecA filament dynamics with single monomer resolution. Cell. 2006; 126:515-527. [PubMed: 16901785]

51. Schlacher K, Cox MM, Woodgate R, Goodman MF. RecA acts in trans to allow replication of damaged DNA by DNA polymerase V. Nature. 2006; 442:883-887. [PubMed: 16929290]

52. Petrova V, Chen SH, Molzberger ET, Tomko E, Chitteni-Pattu S, Jia H, Ordabayev Y, Lohman TM, Cox MM. Active displacement of RecA filaments by UvrD translocase activity. Nucleic Acids Res. 2015; 43:4133-4149. [PubMed: 25824953]

53. Fagerburg MV, Schauer GD, Thickman KR, Bianco PR, Khan SA, Leuba SH, Anand SP. PcrAmediated disruption of RecA nucleoprotein filaments--essential role of the ATPase activity of RecA. Nucleic Acids Res. 2012; 40:8416-8424. [PubMed: 22743269]

54. Park J, Myong S, Niedziela-Majka A, Lee KS, Yu J, Lohman TM, Ha T. PcrA helicase dismantles RecA filaments by reeling in DNA in uniform steps. Cell. 2010; 142:544-555. [PubMed: 20723756]

55. Pham P, Seitz EM, Saveliev S, Shen X, Woodgate R, Cox MM, Goodman MF. Two distinct modes of RecA action are required for DNA polymerase V-catalyzed translesion synthesis. Proc Natl Acad Sci U S A. 2002; 99:11061-11066. [PubMed: 12177433]

56. Schlacher K, Pham P, Cox MM, Goodman MF. Roles of DNA polymerase V and RecA protein in SOS damage-induced mutation. Chem Rev. 2006; 106:406-419. [PubMed: 16464012]

57. Wyatt PJ. Light scattering and the absolute characterization of macromolecules. Anal. Chim. Acta. 1993; 272:1-40.

58. Gruber AJ, Erdem AL, Sabat G, Karata K, Jaszczur MM, Vo DD, Olsen TM, Woodgate R, Goodman MF, Cox MM. A RecA protein surface required for activation of DNA polymerase V. PLoS Genet. 2015; 11:e1005066. [PubMed: 25811184]

59. Sommer S, Boudsocq F, Devoret R, Bailone A. Specific RecA amino acid changes affect RecAUmuD'C interaction. Mol Microbiol. 1998; 28:281-291. [PubMed: 9622353]

60. Schlacher K, Leslie K, Wyman C, Woodgate R, Cox MM, Goodman MF. DNA polymerase V and RecA protein, a minimal mutasome. Mol Cell. 2005; 17:561-572. [PubMed: 15721259]

61. Cox MM, Lehman IR. recA protein of Escherichia coli promotes branch migration, a kinetically distinct phase of DNA strand exchange. Proc Natl Acad Sci U S A. 1981; 78:3433-3437. [PubMed: 7022448]

62. Weinstock GM, McEntee K, Lehman IR. Hydrolysis of nucleoside triphosphates catalyzed by the recA protein of Escherichia coli Hydrolysis of UTP. J Biol Chem. 1981; 256:8856-8858. [PubMed: 7021554]

63. Renzette N, Sandler SJ. Requirements for ATP binding and hydrolysis in RecA function in Escherichia coli. Mol Microbiol. 2008; 67:1347-1359. [PubMed: 18298444]

64. Gruenig MC, Renzette N, Long E, Chitteni-Pattu S, Inman RB, Cox MM, Sandler SJ. RecAmediated SOS induction requires an extended filament conformation but no ATP hydrolysis. Mol Microbiol. 2008; 69:1165-1179. [PubMed: 18627467]

65. Yeeles JT, Marians KJ. Dynamics of leading-strand lesion skipping by the replisome. Mol Cell. 2013; 52:855-865. [PubMed: 24268579]

66. Rowen L, Kornberg A. Primase, the dnaG protein of Escherichia coli An enzyme which starts DNA chains. J Biol Chem. 1978; 253:758-764. [PubMed: 340457]

67. Yeeles JT, Marians KJ. The Escherichia coli replisome is inherently DNA damage tolerant. Science. 2011; 334:235-238. [PubMed: 21998391]

68. Bloom LB, Chen X, Fygenson DK, Turner J, O'Donnell M, Goodman MF. Fidelity of Escherichia coli DNA polymerase III holoenzyme. The effects of beta, gamma complex processivity proteins 
and epsilon proofreading exonuclease on nucleotide misincorporation efficiencies. J Biol Chem. 1997; 272:27919-27930. [PubMed: 9346941]

69. Patricelli MP, Szardenings AK, Liyanage M, Nomanbhoy TK, Wu M, Weissig H, Aban A, Chun D, Tanner S, Kozarich JW. Functional interrogation of the kinome using nucleotide acyl phosphates. Biochemistry. 2007; 46:350-358. [PubMed: 17209545]

70. Yeiser B, Pepper ED, Goodman MF, Finkel SE. SOS-induced DNA polymerases enhance longterm survival and evolutionary fitness. Proc Natl Acad Sci U S A. 2002; 99:8737-8741. [PubMed: 12060704]

71. Corzett CH, Goodman MF, Finkel SE. Competitive fitness during feast and famine: how SOS DNA polymerases influence physiology and evolution in Escherichia coli. Genetics. 2013; 194:409-420. [PubMed: 23589461]

72. Woodgate R, Ennis DG. Levels of chromosomally encoded Umu proteins and requirements for in vivo UmuD cleavage. Mol Gen Genet. 1991; 229:10-16. [PubMed: 1654503] 


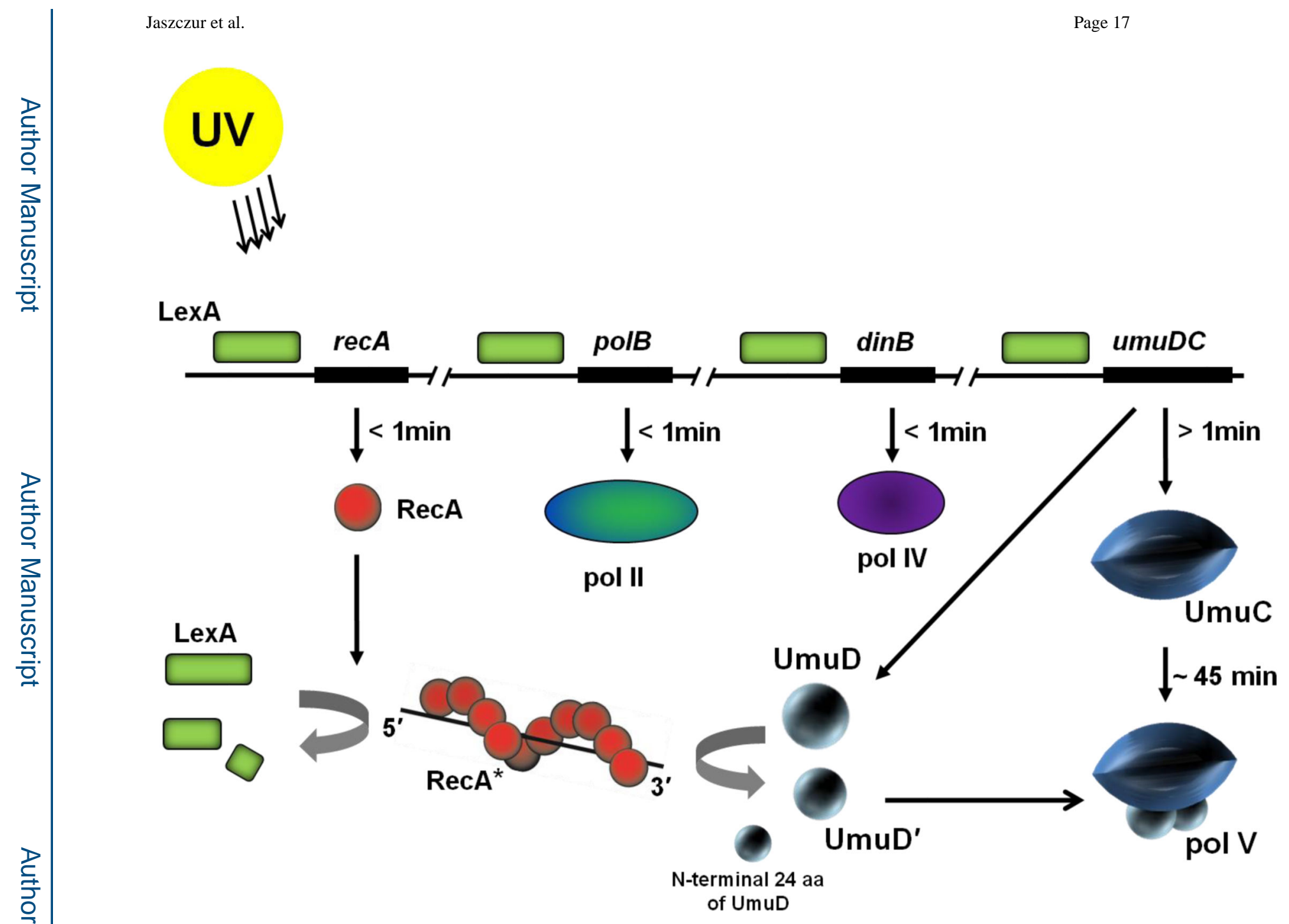

Figure 1.

Induction of TLS DNA polymerases during the SOS response in E. coli. The LexA repressor (green box) binds to a 20 base pair consensus sequence in the operator region of the SOS genes suppressing their expression. Upon UV irradiation, expression of RecA (red spheres) is induced almost immediately after DNA damage occurs. RecA forms a nucleoprotein filament on ssDNA (RecA*) and functions as a coprotease to cleave and thereby inactivate the LexA repressor. Binding affinity of LexA to operon sequences of various SOS genes determine their induction time. Proteins with operators bound weakly by LexA, such as RecA, pol II and pol IV are induced soon after DNA damage occurs whereas proteins with strongly bound operators, such as the $u m u D C$ operon, are induced later(>1 min). ${ }^{11}$ The umuDC operon is fully derepressed $\sim 15 \mathrm{~min}$ after DNA damage, ${ }^{11}$ however, due to rapid proteolysis of the Umu proteins ${ }^{12}$, the $\mathrm{UmuD}_{2}{ }_{2} \mathrm{C}$ complexes themselves do not accumulate until 45 min after damage. RecA* facilitates cleavage of UmuD (15 kDa) to UmuD' (12 $\mathrm{kDa}$ ) removing the first 24 aa from the $\mathrm{N}$-terminus of UmuD. Two molecules of UmuD' $\left(\mathrm{UmuD}_{2}\right)$ form a physical complex with UmuC (48kDa)forming pol V (72 kDa). 


\section{A Bridges-Woodgate Two-Step Model}

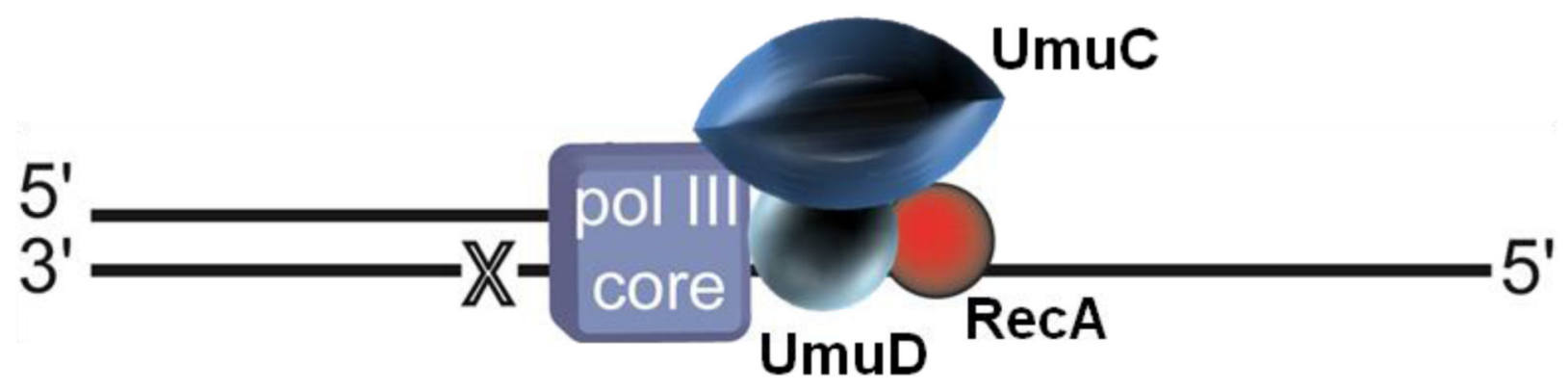

\section{B Echols Mutasome}

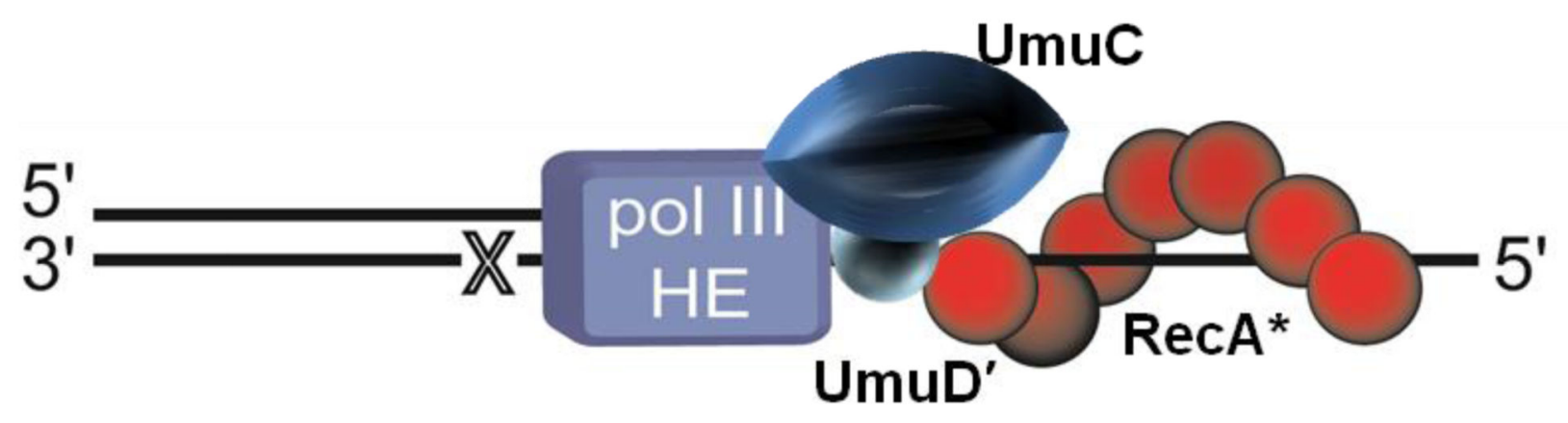

Figure 2.

Translesion synthesis (TLS) models before 1998. (A) The Bridges-Woodgate two-step model. ${ }^{31}$ In this model translesion synthesis (TLS) is catalyzed by DNA polymerase (pol) III that requires a RecA molecule for nucleotide insertion opposite a template lesion (X) and then requires the UV mutagenesis gene products UmuDC to copy past the lesion. (B) The Echols mutasome model. ${ }^{35} \operatorname{RecA}$ nucleoprotein filament (RecA*) assembles in cis at a lesion site $(\mathrm{X})$ on the template strand of DNA being copied. A multiprotein complex, including pol III holoenzyme, UmuC, and UmuD', is then recruited to the DNA allowing TLS resulting in mutations targeted opposite the lesion. 


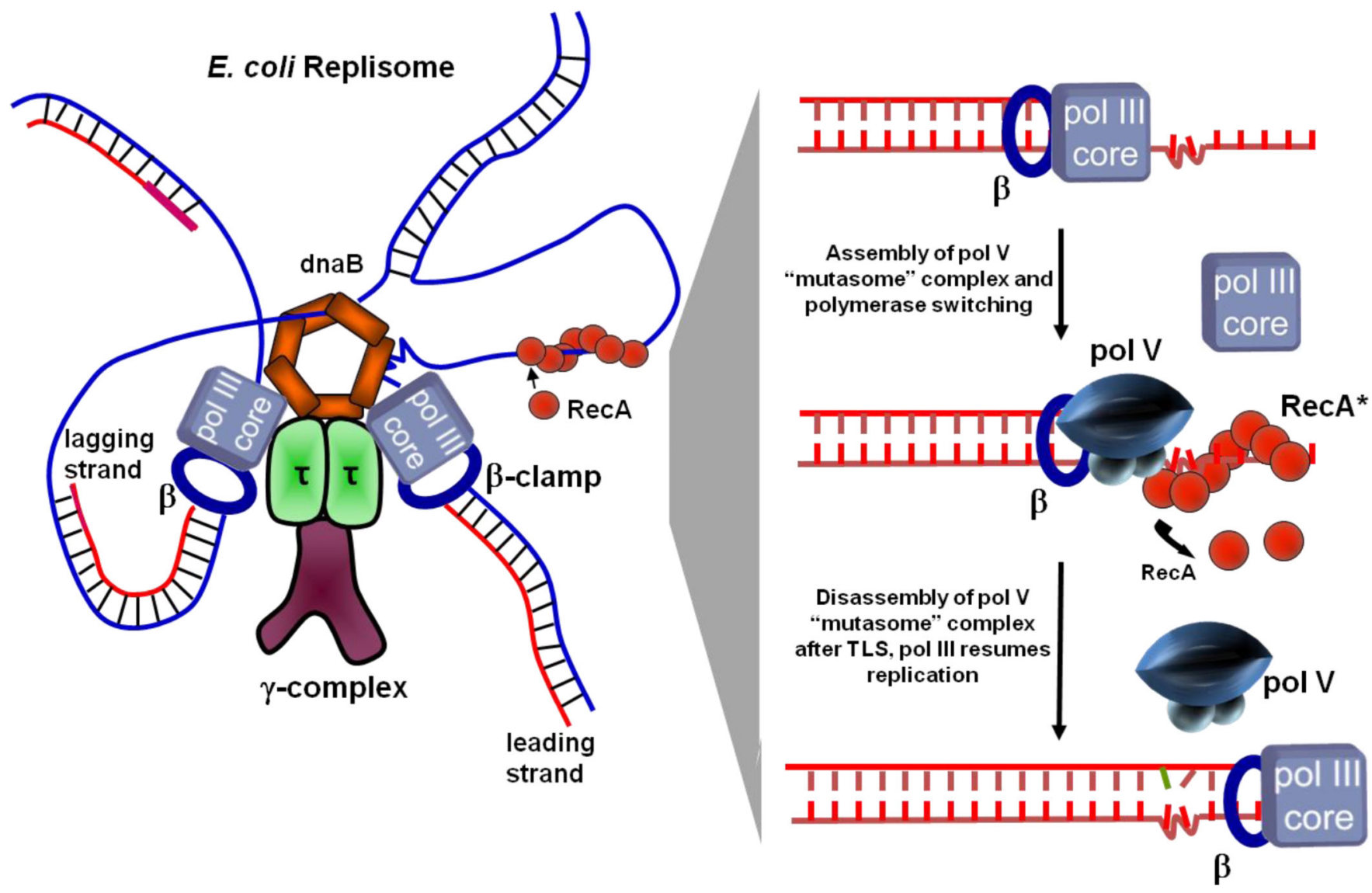

Figure 3.

TLS cis-activation model. A model of an E. coli replisome stalled at a lesion site is depicted in the left panel and individual TLS steps are shown in the right panel. DNA pol III stalls at the lesion site, DnaB helicase unwinds dsDNA ahead of the blocked fork resulting in regions of ssDNA where RecA* assembles in cis. The cis-activation model requires polymerase switching. DNA pol $\mathrm{V}$ replaces pol III core on the $\beta$ clamp and bypasses lesions with concurrent $3^{\prime} \rightarrow 5^{\prime}$ displacement of RecA* formed ahead of the lesion by pol V. Following TLS, pol III core replaces pol V to continue rapid replication of undamaged DNA downstream of the lesion. 


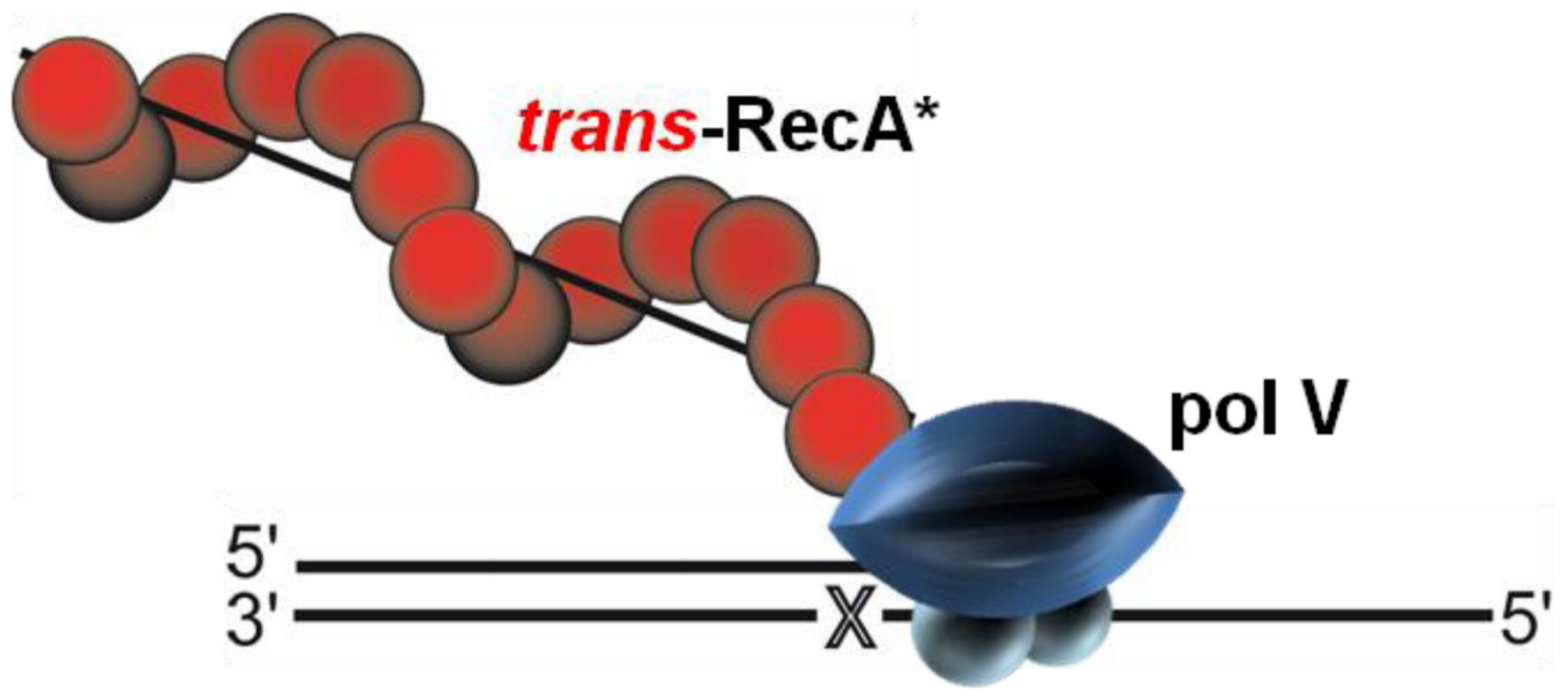

Figure 4.

DNA pol V transactivation by RecA*. RecA* is assembled in trans on ssDNA separate from $\mathrm{p} / \mathrm{t}$ DNA. DNA pol V is then activated by trans-RecA* resulting in TLS. 


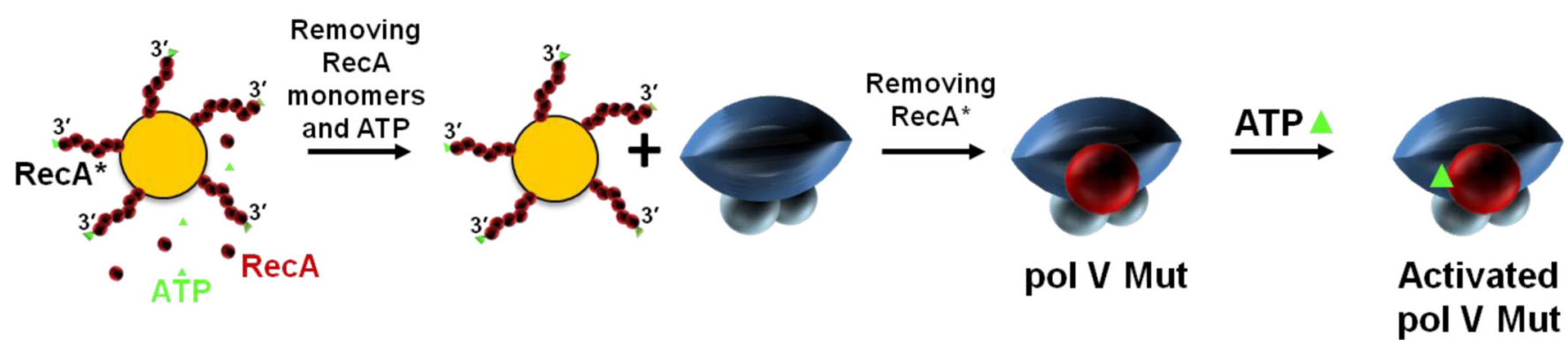

Figure 5.

Pol V Mutasome (Mut). Pol V Mut isolation is a multi-step procedure requiring direct contact between pol V and RecA*. First, RecA* is formed on ssDNA covalently attached to agarose beads, and unbound RecA monomers (red spheres) and ATP (green triangle) are removed by extensive washing. Pol $\mathrm{V}$ is then added. Interaction of pol V with Rec $\mathrm{A}^{*}$ leads to transfer of a RecA subunit from the 3'-proximal tip of RecA* to form pol V Mut. Activated pol V Mut is composed of UmuC-UmuD' ${ }_{2}$-RecA-ATP. 
A

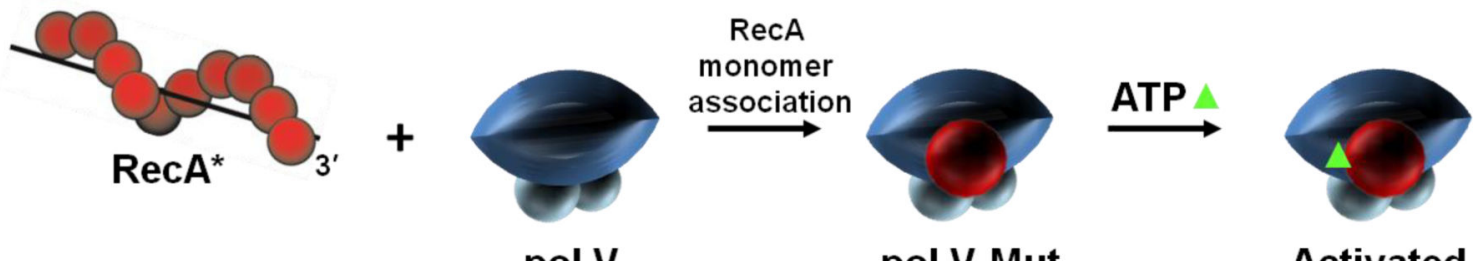

pol V

pol V Mut

Activated

pol V Mut

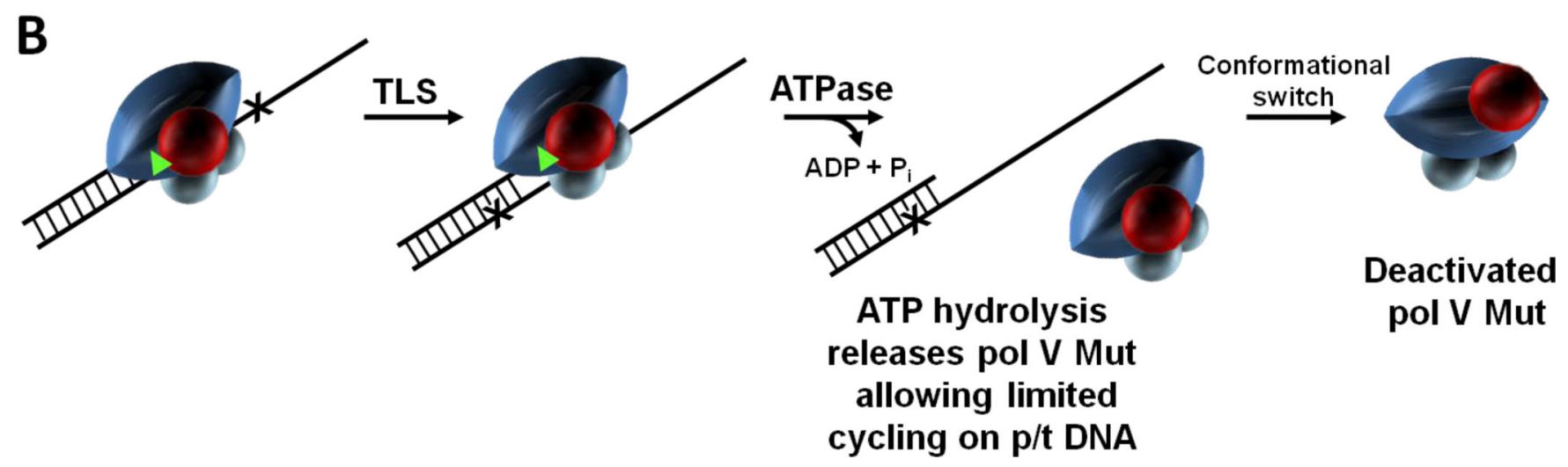

Figure 6.

RecA and ATP regulation of pol V Mut activity. Pol V activity is regulated in multiple steps. (A) First, a RecA subunit is transferred to pol V from the 3'-proximal tip of RecA* to form pol V Mut. Pol V Mut is activated by binding a molecule of ATP (green triangle). (B) Activated pol V Mut associates with p/t DNA and DNA synthesis proceeds until ATP is hydrolyzed. Pol V Mut is a unique DNA-dependent ATPase, where a single ATP hydrolytic event leads to enzyme dissociation from p/t DNA, followed by limited cycling on p/t DNA. After DNA synthesis, pol V Mut becomes deactivated but can be reactivated by exposure to a new RecA*. We propose that active and deactivated pol V Mut are determined by the location of RecA on pol V. 


\section{Cell membrane}

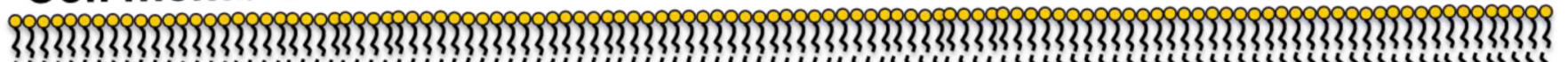

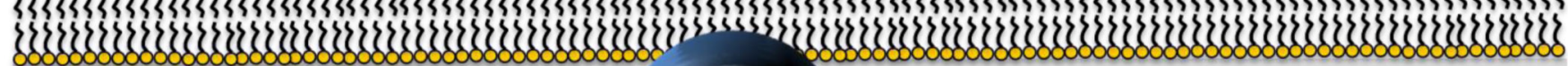

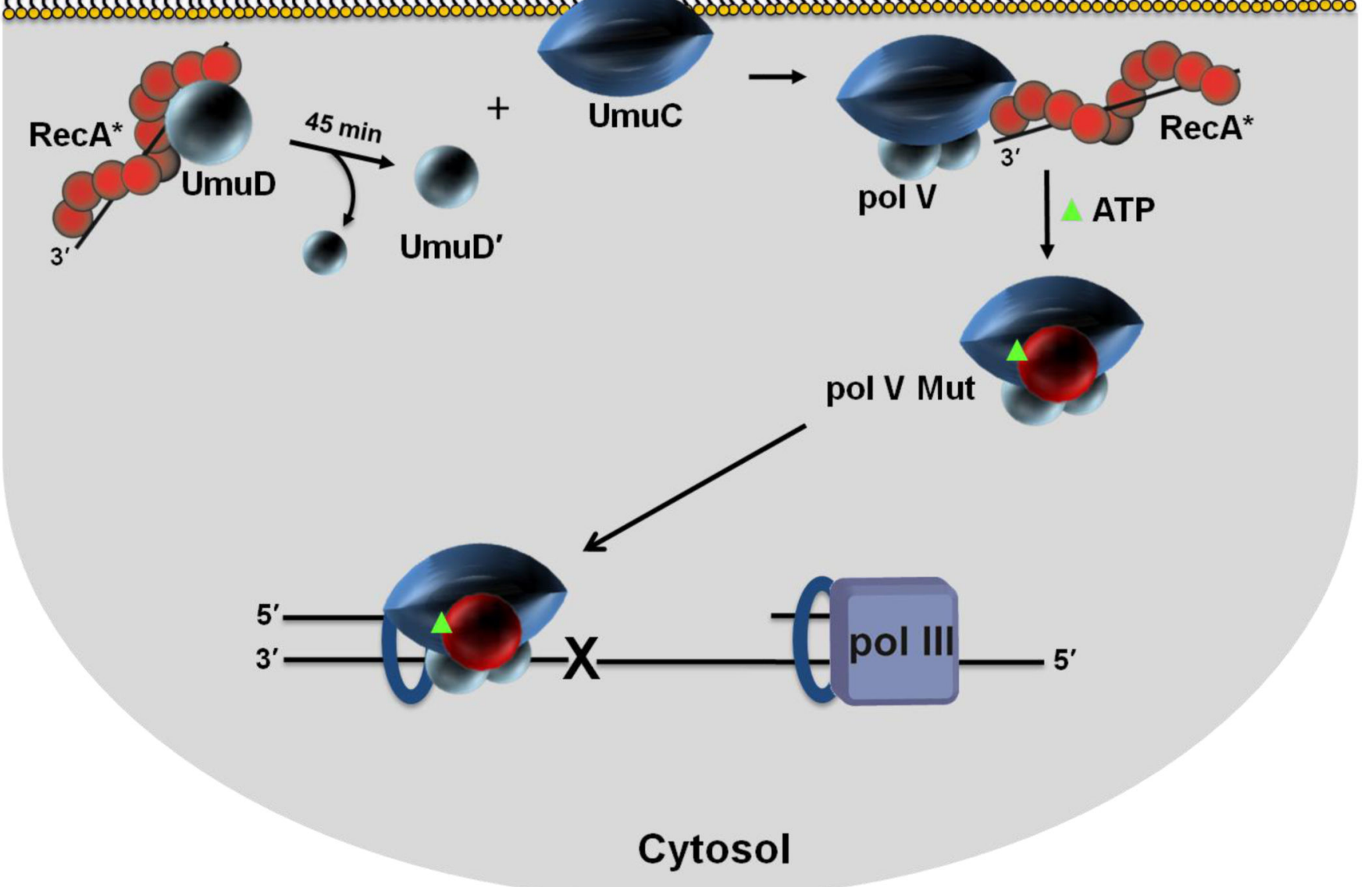

Figure 7.

Spatial regulation of pol V Mut activity in vivo. Sketch depicting cell membrane localization of UmuC. Single molecule live cell fluorescence imaging data indicate that after an initial delay post UV irradiation, UmuC is synthesized and localized on the inner cell membrane. UmuC is released into the cytosol only after it interacts with $\mathrm{UmuD}_{2}$. As RecA and UmuD are found in or near the membrane, additional steps in the formation of pol V Mut (UmuD' ${ }_{2} \mathrm{C}-\mathrm{RecA}$-ATP) may occur in proximity to the membrane. It is not clear what functionality may be associated with the RecA protein found in the membrane. Active RecA*, as studied to date, consists of RecA protein filaments bound to DNA. Sequestration of UmuC at the membrane provides additional levels of pol V Mut regulation. A delay between the production of UmuC and the formation of cytosolic pol V Mut provides time for error-free DNA repair to occur before mutagenic pol V Mut lesion bypass is necessary. 